\title{
Analysis of the upper airway by the acoustic reflection method in children with mucopolysaccharidosis
}

\begin{tabular}{|c|c|}
\hline Journal: & Pediatric Pulmonology \\
\hline Manuscript ID: & PPUL-10-0367.R2 \\
\hline Wiley - Manuscript type: & Original Article \\
\hline $\begin{array}{r}\text { Date Submitted by the } \\
\text { Author: }\end{array}$ & 26-Nov-2010 \\
\hline Complete List of Authors: & $\begin{array}{l}\text { Leboulanger, Nicolas; AP-HP, Armand-Trousseau Children's } \\
\text { Hospital, Pediatric Otolaryngology-Head and Neck Surgery } \\
\text { Department } \\
\text { Louis, Bruno; Université Paris-Est, Faculté de Médecine, U955, } \\
\text { INSERM, Unité U955 } \\
\text { Vialle, Raphael; AP-HP, Armand-Trousseau Children's Hospital, } \\
\text { Pediatric Orthopaedics Department } \\
\text { Heron, Benedicte; AP-HP, Armand-Trousseau Children's Hospital, } \\
\text { Pediatric Neurology Department } \\
\text { Fauroux, Brigitte; Armand Trousseau Hospital, Pediatric } \\
\text { pulmonology and INSERM U } 719\end{array}$ \\
\hline Keywords: & $\begin{array}{l}\text { mucopolysaccharidosis, acoustic reflection method, upper airways, } \\
\text { child, airway resistance, acoustic pharyngometry }\end{array}$ \\
\hline
\end{tabular}

\section{SCHOLARONE ${ }^{\text {M }}$ Manuscripts}


Analysis of the upper airway by the acoustic reflection method in children with mucopolysaccharidosis

Running head: Acoustic reflection in mucopolysaccharidosis

Nicolas LEBOULANGER ${ }^{1,2,3,4,5,8}$ nicolas.leboulanger@trs.aphp.fr

Bruno LOUIS ${ }^{3,4}$ bruno.louis@inserm.fr

Raphaël VIALLE ${ }^{1,6,9}$ raphael.vialle@trs.aphp.fr

Bénédicte HERON ${ }^{1,7,9}$ benedicte.heron@trs.aphp.fr

Brigitte FAUROUX ${ }^{1,4,8,9}$ brigitte.fauroux@trs.aphp.fr

1: UPMC University Paris 06, France

2. Pediatric Otolaryngology-Head and Neck Surgery Department,

3. INSERM, Unité U955, Créteil, F-94010, France ;

4: Université Paris-Est, Faculté de Médecine, U955, Créteil, F-94010, France ;

5. INSERM UMR S-938

6. Pediatric Orthopaedics Department

7. Pediatric Neurology Department

8: Pediatric Pulmonology Department

9: AP-HP, Armand-Trousseau Children's Hospital, 26 Avenue du Dr Arnold Netter 75012 Paris, France

Correspondence to:

Pr. Brigitte FAUROUX

AP-HP, Hôpital Armand-Trousseau

26 avenue du Docteur Arnold-Netter

Paris, F-75012 France

Fax: +33144736174 / Tel: +33144736718

Email: brigitte.fauroux@trs.aphp.fr 


\section{Summary}

\section{Background}

Upper airway obstruction is common in children with mucopolysaccharidosis. The acoustic reflection method is a noninvasive technique that can analyse the calibre of the upper airways. The aim of the study was to evaluate the feasibility of the acoustic reflection method in children with mucopolysaccharidosis, and to compare the characteristics of the upper airways evaluated by the acoustic reflection method in patients with mucopolysaccharidosis to matched healthy counterparts.

\section{Methods}

Open, single centre, prospective, study

\section{Results}

Accurate acoustic reflection measurements could be obtained in 7 of 10 patients (mean age: $10.4 \pm 3.9$ years; mucopolysaccharidosis type II $(n=3)$; type IV $(\mathrm{n}=2)$, type $\mathrm{VI}(\mathrm{n}=1)$, and fucosidosis $(\mathrm{n}=1))$. The mean minimum cross-sectional area was lower in mucopolysaccharidosis patients $\left(1.6 \pm 0.3 \mathrm{~cm}^{2}\right)$ as compared to 14 healthy counterparts $\left(1.8 \pm 0.3 \mathrm{~cm}^{2} ; \mathrm{p}=0.03\right)$. The mean resistance of the airways was significantly higher in the MPS group $\left(7.9 \pm 1.8 \mathrm{cmH}_{2} \mathrm{O} . \mathrm{I}^{-1} . \mathrm{s}\right)$ as compared to the controls $\left(5.5 \pm 1.2 \mathrm{cmH}_{2} \mathrm{O} . \mathrm{I}^{-1} . \mathrm{s} ; \mathrm{p}=0.006\right)$.

\section{Conclusion}

This study is the first to analyze the upper airways by the noninvasive acoustic reflection method in children with mucopolysaccharidosis. Due to a lack of cooperation, reliable measurements could only be obtained in $70 \%$ of a selected group of patients. Children with mucopolysaccharidosis have significant upper airway obstruction as assessed by the reduction of the minimal cross-sectional area of the upper airways and the increase in airway resistance. 
Summary word count: 228

Keywords: mucopolysaccharidosis; acoustic reflection method; acoustic pharyngometry; children; upper airways 


\section{Introduction}

Mucopolysaccharidoses (MPS), OMIM 252700, are a group of rare metabolic inherited disorders caused by the lack or deficiency of specific lysosomal enzymes involved in the degradation of mucopolysaccharids (glycosaminoglycans). ${ }^{1}$ The accumulation of partially degraded molecules interferes with cell, tissue, and organ function. Depending on the MPS subtype, the disease may display various degrees of severity. Mental retardation is common and often severe but may be absent in some MPS (MPS VI).

Upper airway obstruction and its management is a challenging concern in children and adults with MPS. Due to tissue infiltration, airway obstruction may affect the different levels of the respiratory tract. Patients may present narrowed nasal airways, adenotonsillar hypertrophy, macroglossy, thickened tongue, a short and infiltrated neck, and a narrowed pharynx and larynx with a thickened epiglottis. This airway obstruction is associated with an increase in morbidity even in early childhood. ${ }^{2}$. Indeed, severe obstructive sleep apnoea syndrome has been reported in children with MPS..$^{3-7}$ This upper airway obstruction may also complicate the perioperative anaesthetic management, for endotracheal intubation is known to be especially difficult in MPS patients because of soft tissues infiltration and frequent cervical spine malformations. Intubation may require an endoscopic procedure ${ }^{8-10}$ and is not always able to prevent a fatal outcome even for routine procedures. ${ }^{11}$

The acoustic reflection method (ARM) is an interesting noninvasive technique based on the analysis of the reflection of a single transient planar wave, allowing the calculation of the longitudinal cross-sectional area profile of the examined cavity. An analysis of the mechanical properties of the airways by the forced-oscillations method is also possible by this technique. ${ }^{12}$. The ARM has been first reported in humans in 
1980 by Fredberg et al. ${ }^{13}$ Since then, ARM has been used to explore the pharyngeal cavity in snoring patients (acoustic pharyngometry) ${ }^{14,15}$, the nasal compliance (acoustic rhinometry) ${ }^{16}$, the obstruction of endotracheal tubes by mucus plugging ${ }^{17}$, the misplacement of endotracheal tubes ${ }^{18}$, the vocal tract dimensions in adolescents ${ }^{19}$ and in children with Down syndrome. ${ }^{20}$ The ARM has also been used to measure tracheal size and distensibility in healthy adults and patients with cystic fibrosis or achondroplasia. $^{21,22}$

We have recently evaluated the feasibility and established normal values of the upper airways by the ARM in a large group of healthy children. Accurate measurements could be obtained in all the children older than 2 years of age. ${ }^{23}$ Normal values of the minimal cross sectional area (MCAv), which corresponds to the narrowest part of the upper airways (i.e the subglottic region), were established and correlated mainly with height, and to a lesser extend with age and weight. As children with MPS may present upper airway obstruction, we hypothesised that the ARM may be particularly adapted to this population because this technique is noninvasive, simple, and rapid, with a procedure taking less than one minute.

The aim of the present study was to evaluate by the feasibility of the ARM in children with MPS, and to compare the characteristics of the upper airways evaluated by the ARM in patients with MPS to a matched group of healthy children. 


\section{Material and methods}

Patients

The study was proposed to the parents of 10 patients with MPS, followed in our institution and expected to be able to perform the ARM manoeuvre. To be included, the patient had to be free of any acute upper or lower airway disease since at least one month. The ARM measurements were realised during a scheduled hospital visit or hospitalisation.

The following information was assessed from the patient's chart: history of endotracheal intubation and/or any respiratory or upper airway disease, and sleep studies when available.

\section{Control group}

A control group was recruited among siblings of the patients and a large group $(n>60)$ of outpatients from the otolaryngology department (mostly for middle ear surgery). All controls were free of any upper or lower airway disease or symptom since at least 3 months. The control group was secondarily established in order to match with the MPS patients' height, weight, and body mass index (BMI).

The study was approved by our institutional board and written consent was obtained from all the patients and the controls when possible, and all the parents.

\section{The acoustic reflection measurement}

The device used in this study, as well as its calibration method, has been previously described. ${ }^{12,24}$ Briefly, the acoustic reflection device consists in a Plexiglas tube of $22 \mathrm{~cm}$ in length and $16 \mathrm{~mm}$ in diameter. Two microphones (piezoresistive pressure transducers, 8510-B; Endevco France, Le Pré Saint-Gervais, France) are 
inserted on the tube which is connected to a horn driver. The 'microphone' side of the tube is oriented toward the patient, and the other one toward open air. An acoustic wave $(0.2-6 \mathrm{kHz})$ is generated by the horn driver, which is driven by a personal computer via a digital-to-analog converter; microphone outputs are fed into an analog-to-digital converter (14 bits, $24-\mu s$ sampling period).

For a reliable ARM measurement, the subject has to breathe by mouth during $\approx 4 \mathrm{~s}$. As such, only the airways beyond the mouth were analyzed. During these 4 seconds, the ARM device generates 10 consecutive acoustic waves at a frequency of 2.5 $\mathrm{Hz}$ and the corresponding areas distance curves are inferred. As previously shown, ARM measurements are influenced by the position of the head and the connecting equipment. ${ }^{25-28}$ For the recording, the subjects were thus asked to have their head in a neutral position and to breathe through an elastomer mouthpiece (Air Safety Ltd, ref A539, Morecambe, United Kingdom) and a single use filter (Intersurgical Clear-Guard ${ }^{\mathrm{TM}}$, ref 1664, Wokingham, United Kingdom).

Data are given on a 2 dimensional graph with the distance from the end of the wave tube on the $x$-axis and the cross-sectional area on the $y$-axis (Figure 1). A program calculates the cross-sectional area of the airway as a function of the distance along the longitudinal axis with a spatial step increment $\Delta \mathrm{L} \cong 0.4 \mathrm{~cm}$. For every point on the $x$-axis value, i.e. distance on the airway, the mean value of the 10 curves is calculated but if the coefficient of variation of the 10 curves area exceeds $10 \%$ the test is discarded and a new test is performed. A visual control by the operator of the 10 curves (allowing to hand-mark the appropriate areas), as well as the checking of an eventual rejection of a measurement, are systematically associated to this computer analysis. The analysis software also gives the results of each measurement in a numerical format, allowing an accurate estimation of 
surfaces and resistances, as well as the analysis of defined portions of the studied airways chosen by the clinician. For the purpose of the present study, the mean pharyngeal and tracheal cross-sectional airway surface, as well as the minimal airway area value, (MCAv) were calculated. The choice of the landmarks is made according to the curve's profile and the knowledge of the anatomy of the upper airways. Clearly, and by comparison to the classic procedure as recently described by Xue et al. ${ }^{19,20}$, our procedure implies a subjective part in the determination of landmarks. This choice was dictated by the expected lack of cooperation of children with mental retardation. In order to deemphasise the effect of any error on the landmarks definition, we only focussed on parameters that are not, or very partially, affected by the landmarks choice. We used thus the MCAv and mean area over a region of interest and we disregarded the cavity length and the cavity volume.

The software allows also the calculation of the mechanical properties of the respiratory system by the forced oscillations technique, as previously demonstrated. $^{12}$ The system's impedance, defined as the ration between pressure and flow at the mouth, appears as a function of the frequency. Here, the patient's airways' total resistance $(R)$ was defined as the average of the real part of the impedance between 15 and $45 \mathrm{~Hz}$.

\section{Statistical analysis}

Data were expressed as mean \pm standard deviation. Comparison between the patients and the controls was performed using Student's T Test. A p value less than 0.05 was considered statistically significant. 


\section{Results}

Patients and feasibility

Thirty-eight children with a MPS are followed in our institution: MPS III, $\mathrm{n}=22$ (58\%), mean age $11.8 \pm 2.3$ year-old; MPS II, $n=9$ (24\%), mean age $10.3 \pm 1.1$ yearold; MPS IV and VI, $\mathrm{n}=3$ each (8\%), mean age $8.5 \pm 1.7$ and 21 year-old respectively; and $1(2 \%)$ other MPS type, aged 10.5 years. Patients "non suitable for ARM" were pre-selected by our paediatrician neurologist $(\mathrm{BH})$, as they were expected to be unable to perform the ARM manoeuvres because of severe mental retardation and/or major behaviour problems. Ten patients were selected and participated to the study (Figure 2).

Accurate ARM measurements could only be obtained in 7 patients. Indeed, despite pre-selection, 3 patients were unable to breathe normally by mouth for 3 to 4 seconds despite the pre-selection on their capacity, patience, adequate explanations, and parental reassurance (Table 1). No patient with a MPS III could be included because of severe mental retardation and behavioural disorders. One patient had a fucosidosis, considered as a Hurler-like syndrome. ${ }^{29}$

Among the 7 patients, 4 patients had no respiratory symptoms, 3 patients complained of dyspnea at exertion $(n=3)$ and 2 (\#6 and \#7) had documented nocturnal alveolar hypoventilation and were treated by long-term noninvasive positive pressure ventilation (NPPV). The sleep studies of these 2 patients during spontaneous breathing and before initiation of NPPV showed a desaturation index of 34 and 36 per hour, hypoxemia (minimum pulse oximetry $\left(\mathrm{SpO}_{2}\right) 66 \pm 5.6 \%$ ) and hypercapnia (maximum transcutaneous carbon dioxide $\left(\mathrm{PtcCO}_{2}\right) 49 \pm 5.6 \mathrm{mmHg}$ ) (Table 2). One of these two patients previously underwent an endoscopic examination showing an infiltration of the posterior pharyngeal wall, the base of the 
tongue, and the epiglottis, with a tongue base obstruction and a granular aspect of the mucosa.

All patients had previously undergone an endotracheal intubation for a surgical procedure (adenoidectomy, dental care, spine surgery). Four patients (\#1, \#5, \#6 and \#7) had a history of difficult intubation, which required the use of a fiberoptic bronchoscope for 2 of them (\#5 and \#6). None had a history of tracheotomy.

The characteristics of the patients are given in Tables 2 and 3.

\section{Control group}

The control group consisted of 14 healthy children (mean age $7.3 \pm 2$ years) who were matched to the patients with regard to height and weight (Table 3 ). The ARM recording was successful in all the subjects. Due to the impaired growth and development of MPS patients, the healthy subjects matched for height and weight were significantly younger than the patients $(p=0.04)$.

\section{Cross-sectional area values}

The MPS patients had a significantly lower mean MCAv than their healthy counterparts $\left(1.6 \pm 0.3 \mathrm{~cm}^{2}\right.$ and $1.8 \pm 0.3 \mathrm{~cm}^{2}$ for MPS patients and controls, respectively; $p=0.03$ ) (Figure 3 and 4 and Table 3 ). The mean pharyngeal and tracheal area values were also lower in the MPS group than in the controls, but this difference was not statistically significant. Concerning the individual data, MCAv results were clearly different from the controls for 4 MPS patients (patients \#3, \#5, \#6, and \#7). Of note, 2 of these patients (patients \#6 and \#7) were those with severe upper airway obstruction treated with NPPV. Because of the abnormal MCAv results in the two other patients (patients \#3 and \#5), sleep studies were performed. 


\begin{abstract}
Although the results were within the normal range, the apnoea index was 1 and the hypopnoea index was 2 in patient \#3, and the patient \#5 had a hypopnoea index of 5 and spent $12 \%$ of sleep time with a low $\mathrm{SpO}_{2}$ between 90 and $95 \%$.

Upper airways resistance
\end{abstract}

The mean resistance $(R)$ of the upper airways was higher in the MPS group $\left(7.9 \pm 1.8 \mathrm{cmH}_{2} \mathrm{O} . \mathrm{I}^{-1} . \mathrm{s}\right)$ than in the control group $\left(5.5 \pm 1.2 \mathrm{cmH}_{2} \mathrm{O} . \mathrm{I}^{-1} . \mathrm{s}\right)(\mathrm{p}=0.0064)$ (Figure 4 and Table 3).

Again, when looking at the individual data, the $\mathrm{R}$ results were clearly different from the controls for 4 MPS patients (patients \#3, \#4, \#6, and \#7). These 4 patients comprised 3 of the previous patients (patients \#3, \#6, and \#7). The last patient (\#4) is scheduled for a sleep study in the coming weeks.

These complementary data are given in table 2 . 


\section{Discussion}

This study shows that the ARM is able to identify a significant reduction of the upper airway calibre in children with MPS. Indeed, the mean MCAv was significantly lower and the mean airway resistance was significantly higher in 7 patients with MPS as compared to a matched control group. However, individual results were without the normal range in 5 of the 7 patients, of whom 2 were treated with NPPV for severe upper airway obstruction.

Technical issues

We chose the ARM as a tool to study the upper airways in patients with MPS, in whom cooperation may be difficult, because this technique is simple, noninvasive and takes only several seconds. We have recently reported the excellent feasibility of this technique which can be realized in healthy children after the age of 2 years. However, because of a lack of cooperation, mental retardation, and behavioural problems, reliable, accurate ARM measurements could only be obtained in 7 out of 10 selected patients. The experience of our team in performing ARM recordings in children was undoubtedly helpful but was not sufficient. Moreover, if the pre-selection of our patients allowed us to achieve enough successful recordings to obtain workable data, the extension of our results to all the paediatric MPS population must be made with caution. We could only perform ARM measurement in 7/38 (18\%) of all our MPS patients and even if this percentage may be improved (inclusion of adults, multiple examinations in an optimal environment), examination of the total population seems unrealizable. Of note, no patient with a MPS III could be studied. 
Exploring the airways of MPS patients is challenging. Evaluations have been done with CT-scanning but in addition to the irradiation it delivers, this imaging technique also requires cooperation and hold breathing for a few seconds to give reliable data. This seems difficult to achieve in MPS patients, especially in the stressogenic supine position in the scanner machine. ${ }^{30}$ Fiberoptic examination gives accurate morphological data but may also be difficult to perform in children with behavioural problems, and does not provide reliable airway measurements because of the distortion of the images in the optic fibre and the bias of images' interpretation by one practitioner only. However, at least one fiberoptic examination seems recommendable prior to a general anaesthesia in MPS patients. ${ }^{31}$

\section{Clinical relevance of the results}

The MCAv is the most important parameter for the evaluation of the upper airway because the minimal airway diameter influences both the clinical presentation and the therapeutic management. ${ }^{32}$ In healthy subjects, the MCAv corresponds to the subglottic area, which is physiologically the narrowest region of the upper airways. As none of our patients had a history of airway surgery of prolonged intubation, it is likely that their MCAv also corresponds to the subglottic area. The mean MCAv value was significantly reduced in the group of patients with MPS compared to the control group. This can be explained by the infiltration of the airways' wall by the partially degraded molecules inherent to MPS. The mean values of the pharynx and the trachea cross-sectional areas also showed a trend to be reduced compared to healthy children, but this did not reach statistic significance. A significant threshold might have been reached with the inclusion a larger group of patients. Even if the 
ARM has been successfully used in several studies to assess nasal cavities, we intentionally chose not to perform such measurements in our patients because of the difficulty of achieving an accurate nasal recording in patients with behavioural problems.

The overall resistance of the airways was significantly higher in the MPS group as compared to the control group. This can be explained by the modification of the wall compliance, and the reduction of the cross-sectional area of the pharynx, larynx, and trachea, and the lower airways.

Interestingly, the patients with obstructive sleep apnoea and a need for a nocturnal NPPV (\#6 and \#7) had clearly MCAv and airway resistance values outside the normal range. This led us to screen the 3 patients having also abnormal values for upper airway obstruction by a sleep study. The sleep results of these clinically asymptomatic patients were not totally normal (Table 2), underlining the potential value of the ARM as a screening tool for the detection of mild and/or subclinical OSAS in patients with MPS.

Interestingly, MPS patients with abnormal MCAv and airway resistance seemed to be older than those with normal values (12.6 vs. 7.9 years of age). This may be explained by the progressive infiltration of the airways' wall with time. Further studies are warranted to evaluate the usefulness of systematic sleep studies in older patients with MPS in order to detect clinically asymptomatic upper airway obstruction. 


\section{Conclusions}

This study is the first that analyses the upper airways (nose excluded) by the ARM in children with a MPS. Patients with MPS have a significant reduction of the minimal cross-sectional area of the upper airways and an increase of the airways' resistance, as compared to a matched control group. 


\author{
List of abbreviations \\ MPS: mucopolysaccharidosis \\ ARM: acoustic reflection method \\ MCAv: minimum cross-sectional area value \\ BMI: body mass index \\ NRS: noninvasive respiratory support \\ OSAS: obstructive sleep apnea syndrome
}

\title{
Competing interests
}

The authors declare that they have no competing interests.

\section{Authors' contribution}

The study was designed by NL, RV, and BF. Patients' selection was made by $\mathrm{BH}$. Measurements and data management were made by NL. Technical supervision was made by BL. The manuscript was written and approved by all the co-authors.

\begin{abstract}
Authors' information
Nicolas Leboulanger's work is supported by the Société Française d'ORL (SFORL).
\end{abstract}

The research of Brigitte Fauroux is supported by the Association Française contre les Myopathies (AFM), Assistance Publique-Hôpitaux de Paris, INSERM, Legs Poix, ADEP Assistance, and Université Pierre et Marie Curie - Paris 6. 


\section{References}

1. Orphanet. Mucopolysaccharidosis. 2010.

2. Nashed A, Al-Saleh S, Gibbons J, MacLusky I, MacFarlane J, Riekstins A, Clarke J, Narang I. Sleep-related breathing in children with mucopolysaccharidosis. J Inherit Metab Dis 2009;32:544-550.

3. Shih SL, Lee YJ, Lin SP, Sheu CY, Blickman JG. Airway changes in children with mucopolysaccharidoses. Acta Radiol 2002;43:40-43.

4. Yeung $\mathrm{AH}$, Cowan MJ, Horn B, Rosbe KW. Airway management in children with mucopolysaccharidoses. Arch Otolaryngol Head Neck Surg 2009;135:7379.

5. Wold SM, Derkay CS, Darrow DH, Proud V. Role of the pediatric otolaryngologist in diagnosis and management of children with mucopolysaccharidoses. Int J Pediatr Otorhinolaryngol 2010;74:27-31.

6. Simmons MA, Bruce IA, Penney S, Wraith E, Rothera MP. Otorhinolaryngological manifestations of the mucopolysaccharidoses. Int $\mathrm{J}$ Pediatr Otorhinolaryngol 2005;69:589-595.

7. Shinhar SY, Zablocki H, Madgy DN. Airway management in mucopolysaccharide storage disorders. Arch Otolaryngol Head Neck Surg 2004;130:233-237.

8. Aucoin S, Vlatten A, Hackmann T. Difficult airway management with the Bonfils fiberscope in a child with Hurler syndrome. Paediatr Anaesth $2009 ; 19: 421-422$.

9. Belani KG, Krivit W, Carpenter BL, Braunlin E, Buckley JJ, Liao JC, Floyd T, Leonard AS, Summers CG, Levine S, et al. Children with 
mucopolysaccharidosis: perioperative care, morbidity, mortality, and new findings. J Pediatr Surg 1993;28:403-408; discussion 408-410.

10. Walker RW, Darowski M, Morris P, Wraith JE. Anaesthesia and mucopolysaccharidoses. A review of airway problems in children. Anaesthesia 1994;49:1078-1084.

11. Gaitini L, Fradis M, Vaida S, Collins G, Croitoru M, Somri M, Borochovitz Z, Golz A. Failure to control the airway in a patient with Hunter's syndrome. J Laryngol Otol 1998;112:380-382.

12. Louis B, Fodil R, Jaber S, Pigeot J, Jarreau PH, Lofaso F, Isabey D. Dual assessment of airway area profile and respiratory input impedance from a single transient wave. J Appl Physiol 2001;90:630-637.

13. Fredberg JJ, Wohl ME, Glass GM, Dorkin HL. Airway area by acoustic reflections measured at the mouth. J Appl Physiol 1980;48:749-758.

14. Kamal I. Acoustic pharyngometry patterns of snoring and obstructive sleep apnea patients. Otolaryngol Head Neck Surg 2004;130:58-66.

15. Monahan KJ, Larkin EK, Rosen CL, Graham G, Redline S. Utility of noninvasive pharyngometry in epidemiologic studies of childhood sleepdisordered breathing. Am J Respir Crit Care Med 2002;165:1499-1503.

16. Papon JF, Brugel-Ribere L, Fodil R, Croce C, Larger C, Rugina M, Coste A, Isabey D, Zerah-Lancner F, Louis B. Nasal wall compliance in vasomotor rhinitis. J Appl Physiol 2006;100:107-111.

17. Jarreau PH, Louis B, Desfrere L, Blanchard PW, Isabey D, Harf A, Moriette G. Detection of positional airway obstruction in neonates by acoustic reflection. Am J Respir Crit Care Med 2000;161:1754-1756. 
18. Raphael DT, Benbassat M, Arnaudov D, Bohorquez A, Nasseri B. Validation study of two-microphone acoustic reflectometry for determination of breathing tube placement in 200 adult patients. Anesthesiology 2002;97:1371-1377.

19. Xue SA, Cheng RW, Ng LM. Vocal tract dimensional development of adolescents: An acoustic reflection study. Int $\mathrm{J}$ Pediatr Otorhinolaryngol 2010;74:907-912.

20. Xue SA, Kaine L, Ng ML. Quantification of vocal tract configuration of older children with Down syndrome: a pilot study. Int J Pediatr Otorhinolaryngol 2010;74:378-383.

21. Brooks LJ. Tracheal size and distensibility in patients with cystic fibrosis. Am Rev Respir Dis 1990;141:513-516.

22. Stokes DC, Wohl ME, Wise RA, Pyeritz RE, Fairclough DL. The lungs and airways in achondroplasia. Do little people have little lungs? Chest 1990;98:145-152.

23. Leboulanger N, Louis B, Fodil R, Boelle P, Clément A, Garabédian E, Fauroux B. Analysis of the pharynx and the trachea by the acosutic reflection method: a pilot study. Respir Physiol Neurobiol 2010;

24. Louis B, Glass G, Kresen B, Fredberg J. Airway area by acoustic reflection: the two-microphone method. J Biomech Eng 1993;115:278-285.

25. Hellsing $\mathrm{E}$. Changes in the pharyngeal airway in relation to extension of the head. Eur J Orthod 1989;11:359-365.

26. Rubinstein I, McClean PA, Boucher R, Zamel N, Fredberg JJ, Hoffstein V. Effect of mouthpiece, noseclips, and head position on airway area measured by acoustic reflections. J Appl Physiol 1987;63:1469-1474. 
27. Brooks LJ, Byard PJ, Fouke JM, Strohl KP. Reproducibility of measurements of upper airway area by acoustic reflection. J Appl Physiol 1989;66:2901-2905.

28. Brooks LJ, Castile RG, Glass GM, Griscom NT, Wohl ME, Fredberg JJ. Reproducibility and accuracy of airway area by acoustic reflection. J Appl Physiol 1984;57:777-787.

29. Durand P, Borrone C, Della Cella G, Phillippart M. Fucosidosis. The Lancet $1968 ; 1198$.

30. Santamaria F, Andreucci MV, Parenti G, Polverino M, Viggiano D, Montella S, Cesaro A, Ciccarelli R, Capaldo B, Andria G. Upper airway obstructive disease in mucopolysaccharidoses: polysomnography, computed tomography and nasal endoscopy findings. J Inherit Metab Dis 2007;30:743-749.

31. Brambrink AM, Braun U. Airway management in infants and children. Best Pract Res Clin Anaesthesiol 2005;19:675-697.

32. Myer CM, 3rd, O'Connor DM, Cotton RT. Proposed grading system for subglottic stenosis based on endotracheal tube sizes. Ann Otol Rhinol Laryngol 1994;103:319-323. 


\section{Legends of the Figures}

\section{Figure 1}

Typical acoustic recording curves in a healthy subject

Two-dimensional recording; $\mathrm{X}$ : distance from microphones $(\mathrm{cm}) \mathrm{Y}$ : area of airways' cross-section

1: mouthpiece and filter; 2 : mouth and oropharynx 3: pharynx; 4: larynx and trachea; 5: bronchi (artefacts)

\section{Figure 2}

Selection of subjects eligible for the acoustic reflection measurement among the patients with a mucopolysaccharidosis followed in our institution

\section{Figure 3}

An acoustic reflection tracings in a patient with mucopolysaccharidosis (patient). Note the reduced value of the mean cross sectional area and of the cross-sectional area all along the airway (arrows)

\section{Figure 4}

Mean cross sectional area values and resistance values of the patients with mucopolysaccharidosis and the control subjects; black-filled circles correspond to the 2 patients with mucopolysaccharidosis treated by long term noninvasive positive pressure ventilation. 
Table 1: comparison of the patients with mucopolysaccharidosis able or not to perform an adequate acoustic reflection measurement (ARM)

\begin{tabular}{cc|c}
\hline & $\begin{array}{c}\text { Patients able to } \\
\text { perform an ARM } \\
\text { recording } \\
\mathrm{n}=7\end{array}$ & $\begin{array}{c}\text { Patients unable to } \\
\text { perform an ARM } \\
\text { recording } \\
\mathrm{n}=3\end{array}$ \\
\hline $\begin{array}{c}\text { Age }(\mathrm{y}) \\
\begin{array}{c}\text { Gender } \\
\text { Type of MPS } \\
\text { Type II }\end{array}\end{array}$ & $\begin{array}{c}15.2 \\
\mathrm{M}=6 ; \mathrm{n}=3\end{array}$ \\
$\begin{array}{c}\mathrm{n}=1 \\
\text { Type III }\end{array}$ & 3 & 2 \\
Type IV & 0 & 1 \\
Type VI & 2 & 0 \\
Fucosidosis & 1 & 0 \\
\end{tabular}

y: years; M: male; F: female 
Table 2: characteristics of the patients

\begin{tabular}{|c|c|c|c|c|c|c|c|c|c|c|c|c|c|c|}
\hline Patient & Gender & Condition & $\begin{array}{c}\text { Age } \\
(\mathrm{y})\end{array}$ & $\begin{array}{l}\text { Height } \\
(\mathrm{cm})\end{array}$ & $\begin{array}{c}\text { Weight } \\
(\mathrm{kg})\end{array}$ & $\begin{array}{l}\text { Mental } \\
\text { retardation }\end{array}$ & $\begin{array}{l}\text { History of } \\
\text { difficult } \\
\text { intubation }\end{array}$ & $\begin{array}{c}\text { Sleep } \\
\text { study } \\
<6 \\
\text { months }\end{array}$ & $\begin{array}{r}\text { Minimal } \\
\text { sleep } \mathrm{SpO}_{2}\end{array}$ & $\mathrm{RDI}$ & $\begin{array}{l}\mathrm{Dl} \\
(/ \mathrm{h})\end{array}$ & $\begin{array}{c}\text { Snoring } \\
\text { index }\end{array}$ & $\begin{array}{c}\text { Maximal } \\
\text { sleep } \\
\mathrm{CO}_{2} \\
(\mathrm{mmHg})\end{array}$ & NPPV \\
\hline$\# 1$ & M & MPS II: Hunter syndrome & 5.8 & 120 & 30 & Severe & Yes & No & & & & & & No \\
\hline \#2 & M & MPS IV-A: Morquio syndrome & 7 & 110 & 19 & None & No & No & & & & & & No \\
\hline \#3 & M & MPS IV-A: Morquio syndrome & 7.5 & 95 & 17 & None & No & Yes & $93 \%$ & 6 & 0 & 61 & & No \\
\hline \#4 & $\mathrm{F}$ & Fucosidosis & 10.5 & 125 & 25 & Severe & No & No & & & & & & No \\
\hline \#5 & M & MPS II: Hunter syndrome & 11.5 & 135 & 36 & Severe & Yes & Yes & $91 \%$ & 5 & 0 & 55 & 45 & No \\
\hline \#6 & M & MPS II: Hunter syndrome & 15 & 134 & 32 & Severe & Yes & $n / a$ & $65 \%$ & 7 & 34 & 8 & 64 & Yes \\
\hline \#7 & M & $\begin{array}{l}\text { MPS VI: Maroteaux-Lamy } \\
\text { syndrome }\end{array}$ & 15.6 & 131 & 35 & Mild & Yes & $\mathrm{n} / \mathrm{a}$ & $70 \%$ & 17 & 36 & 82 & 53 & Yes \\
\hline
\end{tabular}

M: male; F: female; MPS: mucopolysaccharidosis; y: years; $\mathrm{SpO}_{2}$ : pulse oximetry; RDI: respiratory disturbance index; DI: desaturation index; /h: by hour; $\mathrm{CO}_{2}$ : carbon dioxide; NPPV: noninvasive positive pressure ventilation; n/a: non applicable. 
Table 3: acoustic measurements in MPS patients and healthy subjects

\begin{tabular}{|c|c|c|c|c|c|}
\hline & \multicolumn{2}{|l|}{ MPS patients } & \multicolumn{3}{|c|}{ Healthy subjects } \\
\hline & Mean \pm SD & Range & Mean \pm SD & Range & $\mathbf{p}$ \\
\hline \multicolumn{6}{|l|}{ Anthropometry } \\
\hline Age & $10.4 \pm 3.9$ & $5.8-15.6$ & $7.3 \pm 2$ & 4.1-10.4 & $p=0.04$ \\
\hline Height (cm) & $121.4 \pm 14.6$ & $95-135$ & $120.9 \pm 12$ & $95-133$ & $\mathrm{p}=0.4651$ \\
\hline Weight (kg) & $27.7 \pm 7.5$ & $17-36$ & $26.2 \pm 7.3$ & $19-39$ & $\mathrm{p}=0.3366$ \\
\hline $\mathrm{BMI}\left(\mathrm{kg} \cdot \mathrm{cm}^{-2}\right)$ & $18.5 \pm 2$ & $16-20.8$ & $17.9 \pm 3.5$ & $14.6-22$ & $\mathrm{p}=0.3098$ \\
\hline \multicolumn{6}{|l|}{ Acoustic measurements } \\
\hline $\operatorname{MCAv}\left(\mathrm{cm}^{2}\right)$ & $1.6 \pm 0.3$ & $1.3-2$ & $1.8 \pm 0.3$ & $1.5-2.4$ & $\mathrm{p}=0.0329$ \\
\hline Mean pharyngeal airway surface $\left(\mathrm{cm}^{2}\right)$ & $2.2 \pm 0.6$ & $1.3-2.8$ & $2.5 \pm 0.3$ & $1.9-3.1$ & $\mathrm{p}=0.15$ \\
\hline Mean tracheal airway surface $\left(\mathrm{cm}^{2}\right)$ & $1.8 \pm 0.3$ & $1.3-2.4$ & $2 \pm 0.3$ & $1.7-2.4$ & $p=0.06$ \\
\hline $\mathrm{R}\left(\mathrm{cmH}_{2} \mathrm{O} . \mathrm{I}^{-1} \cdot \mathrm{s}\right)$ & $7.9 \pm 1.8$ & $5.6-10.1$ & $5.5 \pm 1.2$ & 3.3-6.9 & $\mathrm{p}=0.0064$ \\
\hline
\end{tabular}

MPS: mucopolysaccharidosis; SD: standard deviation; BMI: body mass index; R: airway resistance; MCAv: minimal cross-sectional area value 
Analysis of the upper airway by the acoustic reflection method in children with mucopolysaccharidosis

Running head: Acoustic reflection in mucopolysaccharidosis

Nicolas LEBOULANGER ${ }^{1,2,3,4,5,8}$ nicolas.leboulanger@trs.aphp.fr

Bruno LOUIS ${ }^{3,4}$ bruno.louis@inserm.fr

Raphaël VIALLE ${ }^{1,6,9}$ raphael.vialle@trs.aphp.fr

Bénédicte HERON ${ }^{1,7,9}$ benedicte.heron@trs.aphp.fr

Brigitte FAUROUX ${ }^{1,4,8,9}$ brigitte.fauroux@trs.aphp.fr

1: UPMC University Paris 06, France

2. Pediatric Otolaryngology-Head and Neck Surgery Department,

3. INSERM, Unité U955, Créteil, F-94010, France ;

4: Université Paris-Est, Faculté de Médecine, U955, Créteil, F-94010, France ;

5. INSERM UMR S-938

6. Pediatric Orthopaedics Department

7. Pediatric Neurology Department

8: Pediatric Pulmonology Department

9: AP-HP, Armand-Trousseau Children's Hospital, 26 Avenue du Dr Arnold Netter 75012 Paris, France

Correspondence to:

Pr. Brigitte FAUROUX

AP-HP, Hôpital Armand-Trousseau

26 avenue du Docteur Arnold-Netter

Paris, F-75012 France

Fax: +33144736174 / Tel: +33144736718

Email: brigitte.fauroux@trs.aphp.fr 


\section{Summary}

\section{Background}

Upper airway obstruction is common in children with mucopolysaccharidosis. The acoustic reflection method is a noninvasive technique that can analyse the calibre of the upper airways. The aim of the study was to evaluate the feasibility of the acoustic reflection method in children with mucopolysaccharidosis, and to compare the characteristics of the upper airways evaluated by the acoustic reflection method in patients with mucopolysaccharidosis to matched healthy counterparts.

\section{Methods}

Open, single centre, prospective, study

\section{Results}

Accurate acoustic reflection measurements could be obtained in 7 of 10 patients (mean age: $10.4 \pm 3.9$ years; mucopolysaccharidosis type II $(n=3)$; type IV $(\mathrm{n}=2)$, type $\mathrm{VI}(\mathrm{n}=1)$, and fucosidosis $(\mathrm{n}=1))$. The mean minimum cross-sectional area was lower in mucopolysaccharidosis patients $\left(1.6 \pm 0.3 \mathrm{~cm}^{2}\right)$ as compared to 14 healthy counterparts $\left(1.8 \pm 0.3 \mathrm{~cm}^{2} ; \mathrm{p}=0.03\right)$. The mean resistance of the airways was significantly higher in the MPS group $\left(7.9 \pm 1.8 \mathrm{cmH}_{2} \mathrm{O} . \mathrm{I}^{-1} . \mathrm{s}\right)$ as compared to the controls $\left(5.5 \pm 1.2 \mathrm{cmH}_{2} \mathrm{O} . \mathrm{I}^{-1} . \mathrm{s} ; \mathrm{p}=0.006\right)$.

\section{Conclusion}

This study is the first to analyze the upper airways by the noninvasive acoustic reflection method in children with mucopolysaccharidosis. Due to a lack of cooperation, reliable measurements could only be obtained in $70 \%$ of a selected group of patients. Children with mucopolysaccharidosis have significant upper airway obstruction as assessed by the reduction of the minimal cross-sectional area of the upper airways and the increase in airway resistance. 
Summary word count: 228

Keywords: mucopolysaccharidosis; acoustic reflection method; acoustic pharyngometry; children; upper airways 


\section{Introduction}

Mucopolysaccharidoses (MPS), OMIM 252700, are a group of rare metabolic inherited disorders caused by the lack or deficiency of specific lysosomal enzymes involved in the degradation of mucopolysaccharids (glycosaminoglycans). ${ }^{1}$ The accumulation of partially degraded molecules interferes with cell, tissue, and organ function. Depending on the MPS subtype, the disease may display various degrees of severity. Mental retardation is common and often severe but may be absent in some MPS (MPS VI).

Upper airway obstruction and its management is a challenging concern in children and adults with MPS. Due to tissue infiltration, airway obstruction may affect the different levels of the respiratory tract. Patients may present narrowed nasal airways, adenotonsillar hypertrophy, macroglossy, thickened tongue, a short and infiltrated neck, and a narrowed pharynx and larynx with a thickened epiglottis. This airway obstruction is associated with an increase in morbidity even in early childhood. ${ }^{2}$. Indeed, severe obstructive sleep apnoea syndrome has been reported in children with MPS..$^{3-7}$ This upper airway obstruction may also complicate the perioperative anaesthetic management, for endotracheal intubation is known to be especially difficult in MPS patients because of soft tissues infiltration and frequent cervical spine malformations. Intubation may require an endoscopic procedure ${ }^{8-10}$ and is not always able to prevent a fatal outcome even for routine procedures. ${ }^{11}$

The acoustic reflection method (ARM) is an interesting noninvasive technique based on the analysis of the reflection of a single transient planar wave, allowing the calculation of the longitudinal cross-sectional area profile of the examined cavity. An analysis of the mechanical properties of the airways by the forced-oscillations method is also possible by this technique. ${ }^{12}$. The ARM has been first reported in humans in 
1980 by Fredberg et al. ${ }^{13}$ Since then, ARM has been used to explore the pharyngeal cavity in snoring patients (acoustic pharyngometry) ${ }^{14,15}$, the nasal compliance (acoustic rhinometry) ${ }^{16}$, the obstruction of endotracheal tubes by mucus plugging ${ }^{17}$, the misplacement of endotracheal tubes ${ }^{18}$, the vocal tract dimensions in adolescents ${ }^{19}$ and in children with Down syndrome. ${ }^{20}$ The ARM has also been used to measure tracheal size and distensibility in healthy adults and patients with cystic fibrosis or achondroplasia. $^{21,22}$

We have recently evaluated the feasibility and established normal values of the upper airways by the ARM in a large group of healthy children. Accurate measurements could be obtained in all the children older than 2 years of age. ${ }^{23}$ Normal values of the minimal cross sectional area (MCAv), which corresponds to the narrowest part of the upper airways (i.e the subglottic region), were established and correlated mainly with height, and to a lesser extend with age and weight. As children with MPS may present upper airway obstruction, we hypothesised that the ARM may be particularly adapted to this population because this technique is noninvasive, simple, and rapid, with a procedure taking less than one minute.

The aim of the present study was to evaluate by the feasibility of the ARM in children with MPS, and to compare the characteristics of the upper airways evaluated by the ARM in patients with MPS to a matched group of healthy children. 


\section{Material and methods}

Patients

The study was proposed to the parents of 10 patients with MPS, followed in our institution and expected to be able to perform the ARM manoeuvre. To be included, the patient had to be free of any acute upper or lower airway disease since at least one month. The ARM measurements were realised during a scheduled hospital visit or hospitalisation.

The following information was assessed from the patient's chart: history of endotracheal intubation and/or any respiratory or upper airway disease, and sleep studies when available.

\section{Control group}

A control group was recruited among siblings of the patients and a large group $(n>60)$ of outpatients from the otolaryngology department (mostly for middle ear surgery). All controls were free of any upper or lower airway disease or symptom since at least 3 months. The control group was secondarily established in order to match with the MPS patients' height, weight, and body mass index (BMI).

The study was approved by our institutional board and written consent was obtained from all the patients and the controls when possible, and all the parents.

\section{The acoustic reflection measurement}

The device used in this study, as well as its calibration method, has been previously described. ${ }^{12,24}$ Briefly, the acoustic reflection device consists in a Plexiglas tube of $22 \mathrm{~cm}$ in length and $16 \mathrm{~mm}$ in diameter. Two microphones (piezoresistive pressure transducers, 8510-B; Endevco France, Le Pré Saint-Gervais, France) are 
inserted on the tube which is connected to a horn driver. The 'microphone' side of the tube is oriented toward the patient, and the other one toward open air. An acoustic wave $(0.2-6 \mathrm{kHz})$ is generated by the horn driver, which is driven by a personal computer via a digital-to-analog converter; microphone outputs are fed into an analog-to-digital converter (14 bits, $24-\mu s$ sampling period).

For a reliable ARM measurement, the subject has to breathe by mouth during $\approx 4 \mathrm{~s}$. As such, only the airways beyond the mouth were analyzed. During these 4 seconds, the ARM device generates 10 consecutive acoustic waves at a frequency of 2.5 $\mathrm{Hz}$ and the corresponding areas distance curves are inferred. As previously shown, ARM measurements are influenced by the position of the head and the connecting equipment. ${ }^{25-28}$ For the recording, the subjects were thus asked to have their head in a neutral position and to breathe through an elastomer mouthpiece (Air Safety Ltd, ref A539, Morecambe, United Kingdom) and a single use filter (Intersurgical Clear-Guard ${ }^{\mathrm{TM}}$, ref 1664, Wokingham, United Kingdom).

Data are given on a 2 dimensional graph with the distance from the end of the wave tube on the $x$-axis and the cross-sectional area on the $y$-axis (Figure 1). A program calculates the cross-sectional area of the airway as a function of the distance along the longitudinal axis with a spatial step increment $\Delta \mathrm{L} \cong 0.4 \mathrm{~cm}$. For every point on the $x$-axis value, i.e. distance on the airway, the mean value of the 10 curves is calculated but if the coefficient of variation of the 10 curves area exceeds $10 \%$ the test is discarded and a new test is performed. A visual control by the operator of the 10 curves (allowing to hand-mark the appropriate areas), as well as the checking of an eventual rejection of a measurement, are systematically associated to this computer analysis. The analysis software also gives the results of each measurement in a numerical format, allowing an accurate estimation of 
surfaces and resistances, as well as the analysis of defined portions of the studied airways chosen by the clinician. For the purpose of the present study, the mean pharyngeal and tracheal cross-sectional airway surface, as well as the minimal airway area value, (MCAv) were calculated. The choice of the landmarks is made according to the curve's profile and the knowledge of the anatomy of the upper airways. Clearly, and by comparison to the classic procedure as recently described by Xue et al. ${ }^{19,20}$, our procedure implies a subjective part in the determination of landmarks. This choice was dictated by the expected lack of cooperation of children with mental retardation. In order to deemphasise the effect of any error on the landmarks definition, we only focussed on parameters that are not, or very partially, affected by the landmarks choice. We used thus the MCAv and mean area over a region of interest and we disregarded the cavity length and the cavity volume.

The software allows also the calculation of the mechanical properties of the respiratory system by the forced oscillations technique, as previously demonstrated. $^{12}$ The system's impedance, defined as the ration between pressure and flow at the mouth, appears as a function of the frequency. Here, the patient's airways' total resistance $(R)$ was defined as the average of the real part of the impedance between 15 and $45 \mathrm{~Hz}$.

\section{Statistical analysis}

Data were expressed as mean \pm standard deviation. Comparison between the patients and the controls was performed using Student's T Test. A p value less than 0.05 was considered statistically significant. 


\section{Results}

Patients and feasibility

Thirty-eight children with a MPS are followed in our institution: MPS III, $\mathrm{n}=22$ (58\%), mean age $11.8 \pm 2.3$ year-old; MPS II, $n=9$ (24\%), mean age $10.3 \pm 1.1$ yearold; MPS IV and VI, $\mathrm{n}=3$ each (8\%), mean age $8.5 \pm 1.7$ and 21 year-old respectively; and $1(2 \%)$ other MPS type, aged 10.5 years. Patients "non suitable for ARM" were pre-selected by our paediatrician neurologist $(\mathrm{BH})$, as they were expected to be unable to perform the ARM manoeuvres because of severe mental retardation and/or major behaviour problems. Ten patients were selected and participated to the study (Figure 2).

Accurate ARM measurements could only be obtained in 7 patients. Indeed, despite pre-selection, 3 patients were unable to breathe normally by mouth for 3 to 4 seconds despite the pre-selection on their capacity, patience, adequate explanations, and parental reassurance (Table 1). No patient with a MPS III could be included because of severe mental retardation and behavioural disorders. One patient had a fucosidosis, considered as a Hurler-like syndrome. ${ }^{29}$

Among the 7 patients, 4 patients had no respiratory symptoms, 3 patients complained of dyspnea at exertion $(n=3)$ and 2 (\#6 and \#7) had documented nocturnal alveolar hypoventilation and were treated by long-term noninvasive positive pressure ventilation (NPPV). The sleep studies of these 2 patients during spontaneous breathing and before initiation of NPPV showed a desaturation index of 34 and 36 per hour, hypoxemia (minimum pulse oximetry $\left(\mathrm{SpO}_{2}\right) 66 \pm 5.6 \%$ ) and hypercapnia (maximum transcutaneous carbon dioxide $\left(\mathrm{PtcCO}_{2}\right) 49 \pm 5.6 \mathrm{mmHg}$ ) (Table 2). One of these two patients previously underwent an endoscopic examination showing an infiltration of the posterior pharyngeal wall, the base of the 
tongue, and the epiglottis, with a tongue base obstruction and a granular aspect of the mucosa.

All patients had previously undergone an endotracheal intubation for a surgical procedure (adenoidectomy, dental care, spine surgery). Four patients (\#1, \#5, \#6 and \#7) had a history of difficult intubation, which required the use of a fiberoptic bronchoscope for 2 of them (\#5 and \#6). None had a history of tracheotomy.

The characteristics of the patients are given in Tables 2 and 3.

\section{Control group}

The control group consisted of 14 healthy children (mean age $7.3 \pm 2$ years) who were matched to the patients with regard to height and weight (Table 3 ). The ARM recording was successful in all the subjects. Due to the impaired growth and development of MPS patients, the healthy subjects matched for height and weight were significantly younger than the patients $(p=0.04)$.

\section{Cross-sectional area values}

The MPS patients had a significantly lower mean MCAv than their healthy counterparts $\left(1.6 \pm 0.3 \mathrm{~cm}^{2}\right.$ and $1.8 \pm 0.3 \mathrm{~cm}^{2}$ for MPS patients and controls, respectively; $p=0.03$ ) (Figure 3 and 4 and Table 3 ). The mean pharyngeal and tracheal area values were also lower in the MPS group than in the controls, but this difference was not statistically significant. Concerning the individual data, MCAv results were clearly different from the controls for 4 MPS patients (patients \#3, \#5, \#6, and \#7). Of note, 2 of these patients (patients \#6 and \#7) were those with severe upper airway obstruction treated with NPPV. Because of the abnormal MCAv results in the two other patients (patients \#3 and \#5), sleep studies were performed. 
Although the results were within the normal range, the apnoea index was 1 and the hypopnoea index was 2 in patient \#3, and the patient \#5 had a hypopnoea index of 5 and spent $12 \%$ of sleep time with a low $\mathrm{SpO}_{2}$ between 90 and $95 \%$.

Upper airways resistance

The mean resistance $(R)$ of the upper airways was higher in the MPS group $\left(7.9 \pm 1.8 \mathrm{cmH}_{2} \mathrm{O} . \mathrm{I}^{-1} . \mathrm{s}\right)$ than in the control group $\left(5.5 \pm 1.2 \mathrm{cmH}_{2} \mathrm{O} . \mathrm{I}^{-1} . \mathrm{s}\right)(\mathrm{p}=0.0064)$ (Figure 4 and Table 3).

Again, when looking at the individual data, the $\mathrm{R}$ results were clearly different from the controls for 4 MPS patients (patients \#3, \#4, \#6, and \#7). These 4 patients comprised 3 of the previous patients (patients \#3, \#6, and \#7). The last patient (\#4) is scheduled for a sleep study in the coming weeks.

These complementary data are given in table 2 . 


\section{Discussion}

This study shows that the ARM is able to identify a significant reduction of the upper airway calibre in children with MPS. Indeed, the mean MCAv was significantly lower and the mean airway resistance was significantly higher in 7 patients with MPS as compared to a matched control group. However, individual results were without the normal range in 5 of the 7 patients, of whom 2 were treated with NPPV for severe upper airway obstruction.

Technical issues

We chose the ARM as a tool to study the upper airways in patients with MPS, in whom cooperation may be difficult, because this technique is simple, noninvasive and takes only several seconds. We have recently reported the excellent feasibility of this technique which can be realized in healthy children after the age of 2 years. However, because of a lack of cooperation, mental retardation, and behavioural problems, reliable, accurate ARM measurements could only be obtained in 7 out of 10 selected patients. The experience of our team in performing ARM recordings in children was undoubtedly helpful but was not sufficient. Moreover, if the pre-selection of our patients allowed us to achieve enough successful recordings to obtain workable data, the extension of our results to all the paediatric MPS population must be made with caution. We could only perform ARM measurement in 7/38 (18\%) of all our MPS patients and even if this percentage may be improved (inclusion of adults, multiple examinations in an optimal environment), examination of the total population seems unrealizable. Of note, no patient with a MPS III could be studied. 
Exploring the airways of MPS patients is challenging. Evaluations have been done with CT-scanning but in addition to the irradiation it delivers, this imaging technique also requires cooperation and hold breathing for a few seconds to give reliable data. This seems difficult to achieve in MPS patients, especially in the stressogenic supine position in the scanner machine. ${ }^{30}$ Fiberoptic examination gives accurate morphological data but may also be difficult to perform in children with behavioural problems, and does not provide reliable airway measurements because of the distortion of the images in the optic fibre and the bias of images' interpretation by one practitioner only. However, at least one fiberoptic examination seems recommendable prior to a general anaesthesia in MPS patients. ${ }^{31}$

\section{Clinical relevance of the results}

The MCAv is the most important parameter for the evaluation of the upper airway because the minimal airway diameter influences both the clinical presentation and the therapeutic management. ${ }^{32}$ In healthy subjects, the MCAv corresponds to the subglottic area, which is physiologically the narrowest region of the upper airways. As none of our patients had a history of airway surgery of prolonged intubation, it is likely that their MCAv also corresponds to the subglottic area. The mean MCAv value was significantly reduced in the group of patients with MPS compared to the control group. This can be explained by the infiltration of the airways' wall by the partially degraded molecules inherent to MPS. The mean values of the pharynx and the trachea cross-sectional areas also showed a trend to be reduced compared to healthy children, but this did not reach statistic significance. A significant threshold might have been reached with the inclusion a larger group of patients. Even if the 
ARM has been successfully used in several studies to assess nasal cavities, we intentionally chose not to perform such measurements in our patients because of the difficulty of achieving an accurate nasal recording in patients with behavioural problems.

The overall resistance of the airways was significantly higher in the MPS group as compared to the control group. This can be explained by the modification of the wall compliance, and the reduction of the cross-sectional area of the pharynx, larynx, and trachea, and the lower airways.

Interestingly, the patients with obstructive sleep apnoea and a need for a nocturnal NPPV (\#6 and \#7) had clearly MCAv and airway resistance values outside the normal range. This led us to screen the 3 patients having also abnormal values for upper airway obstruction by a sleep study. The sleep results of these clinically asymptomatic patients were not totally normal (Table 2), underlining the potential value of the ARM as a screening tool for the detection of mild and/or subclinical OSAS in patients with MPS.

Interestingly, MPS patients with abnormal MCAv and airway resistance seemed to be older than those with normal values (12.6 vs. 7.9 years of age). This may be explained by the progressive infiltration of the airways' wall with time. Further studies are warranted to evaluate the usefulness of systematic sleep studies in older patients with MPS in order to detect clinically asymptomatic upper airway obstruction. 


\section{Conclusions}

This study is the first that analyses the upper airways (nose excluded) by the ARM in children with a MPS. Patients with MPS have a significant reduction of the minimal cross-sectional area of the upper airways and an increase of the airways' resistance, as compared to a matched control group. 


\author{
List of abbreviations \\ MPS: mucopolysaccharidosis \\ ARM: acoustic reflection method \\ MCAv: minimum cross-sectional area value \\ BMI: body mass index \\ NRS: noninvasive respiratory support \\ OSAS: obstructive sleep apnea syndrome
}

\title{
Competing interests
}

The authors declare that they have no competing interests.

\section{Authors' contribution}

The study was designed by NL, RV, and BF. Patients' selection was made by $\mathrm{BH}$. Measurements and data management were made by NL. Technical supervision was made by BL. The manuscript was written and approved by all the co-authors.

\begin{abstract}
Authors' information
Nicolas Leboulanger's work is supported by the Société Française d'ORL (SFORL).
\end{abstract}

The research of Brigitte Fauroux is supported by the Association Française contre les Myopathies (AFM), Assistance Publique-Hôpitaux de Paris, INSERM, Legs Poix, ADEP Assistance, and Université Pierre et Marie Curie - Paris 6. 


\section{References}

1. Orphanet. Mucopolysaccharidosis. 2010.

2. Nashed A, Al-Saleh S, Gibbons J, MacLusky I, MacFarlane J, Riekstins A, Clarke J, Narang I. Sleep-related breathing in children with mucopolysaccharidosis. J Inherit Metab Dis 2009;32:544-550.

3. Shih SL, Lee YJ, Lin SP, Sheu CY, Blickman JG. Airway changes in children with mucopolysaccharidoses. Acta Radiol 2002;43:40-43.

4. Yeung $\mathrm{AH}$, Cowan MJ, Horn B, Rosbe KW. Airway management in children with mucopolysaccharidoses. Arch Otolaryngol Head Neck Surg 2009;135:7379.

5. Wold SM, Derkay CS, Darrow DH, Proud V. Role of the pediatric otolaryngologist in diagnosis and management of children with mucopolysaccharidoses. Int J Pediatr Otorhinolaryngol 2010;74:27-31.

6. Simmons MA, Bruce IA, Penney S, Wraith E, Rothera MP. Otorhinolaryngological manifestations of the mucopolysaccharidoses. Int $\mathrm{J}$ Pediatr Otorhinolaryngol 2005;69:589-595.

7. Shinhar SY, Zablocki H, Madgy DN. Airway management in mucopolysaccharide storage disorders. Arch Otolaryngol Head Neck Surg 2004;130:233-237.

8. Aucoin S, Vlatten A, Hackmann T. Difficult airway management with the Bonfils fiberscope in a child with Hurler syndrome. Paediatr Anaesth $2009 ; 19: 421-422$.

9. Belani KG, Krivit W, Carpenter BL, Braunlin E, Buckley JJ, Liao JC, Floyd T, Leonard AS, Summers CG, Levine S, et al. Children with 
mucopolysaccharidosis: perioperative care, morbidity, mortality, and new findings. J Pediatr Surg 1993;28:403-408; discussion 408-410.

10. Walker RW, Darowski M, Morris P, Wraith JE. Anaesthesia and mucopolysaccharidoses. A review of airway problems in children. Anaesthesia 1994;49:1078-1084.

11. Gaitini L, Fradis M, Vaida S, Collins G, Croitoru M, Somri M, Borochovitz Z, Golz A. Failure to control the airway in a patient with Hunter's syndrome. J Laryngol Otol 1998;112:380-382.

12. Louis B, Fodil R, Jaber S, Pigeot J, Jarreau PH, Lofaso F, Isabey D. Dual assessment of airway area profile and respiratory input impedance from a single transient wave. J Appl Physiol 2001;90:630-637.

13. Fredberg JJ, Wohl ME, Glass GM, Dorkin HL. Airway area by acoustic reflections measured at the mouth. J Appl Physiol 1980;48:749-758.

14. Kamal I. Acoustic pharyngometry patterns of snoring and obstructive sleep apnea patients. Otolaryngol Head Neck Surg 2004;130:58-66.

15. Monahan KJ, Larkin EK, Rosen CL, Graham G, Redline S. Utility of noninvasive pharyngometry in epidemiologic studies of childhood sleepdisordered breathing. Am J Respir Crit Care Med 2002;165:1499-1503.

16. Papon JF, Brugel-Ribere L, Fodil R, Croce C, Larger C, Rugina M, Coste A, Isabey D, Zerah-Lancner F, Louis B. Nasal wall compliance in vasomotor rhinitis. J Appl Physiol 2006;100:107-111.

17. Jarreau PH, Louis B, Desfrere L, Blanchard PW, Isabey D, Harf A, Moriette G. Detection of positional airway obstruction in neonates by acoustic reflection. Am J Respir Crit Care Med 2000;161:1754-1756. 
18. Raphael DT, Benbassat M, Arnaudov D, Bohorquez A, Nasseri B. Validation study of two-microphone acoustic reflectometry for determination of breathing tube placement in 200 adult patients. Anesthesiology 2002;97:1371-1377.

19. Xue SA, Cheng RW, $\mathrm{Ng}$ LM. Vocal tract dimensional development of adolescents: An acoustic reflection study. Int $\mathrm{J}$ Pediatr Otorhinolaryngol 2010;74:907-912.

20. Xue SA, Kaine L, Ng ML. Quantification of vocal tract configuration of older children with Down syndrome: a pilot study. Int J Pediatr Otorhinolaryngol 2010;74:378-383.

21. Brooks LJ. Tracheal size and distensibility in patients with cystic fibrosis. Am Rev Respir Dis 1990;141:513-516.

22. Stokes DC, Wohl ME, Wise RA, Pyeritz RE, Fairclough DL. The lungs and airways in achondroplasia. Do little people have little lungs? Chest 1990;98:145-152.

23. Leboulanger N, Louis B, Fodil R, Boelle P, Clément A, Garabédian E, Fauroux B. Analysis of the pharynx and the trachea by the acosutic reflection method: a pilot study. Respir Physiol Neurobiol 2010;

24. Louis B, Glass G, Kresen B, Fredberg J. Airway area by acoustic reflection: the two-microphone method. J Biomech Eng 1993;115:278-285.

25. Hellsing $\mathrm{E}$. Changes in the pharyngeal airway in relation to extension of the head. Eur J Orthod 1989;11:359-365.

26. Rubinstein I, McClean PA, Boucher R, Zamel N, Fredberg JJ, Hoffstein V. Effect of mouthpiece, noseclips, and head position on airway area measured by acoustic reflections. J Appl Physiol 1987;63:1469-1474. 
27. Brooks LJ, Byard PJ, Fouke JM, Strohl KP. Reproducibility of measurements of upper airway area by acoustic reflection. J Appl Physiol 1989;66:2901-2905.

28. Brooks LJ, Castile RG, Glass GM, Griscom NT, Wohl ME, Fredberg JJ. Reproducibility and accuracy of airway area by acoustic reflection. J Appl Physiol 1984;57:777-787.

29. Durand P, Borrone C, Della Cella G, Phillippart M. Fucosidosis. The Lancet $1968 ; 1198$.

30. Santamaria F, Andreucci MV, Parenti G, Polverino M, Viggiano D, Montella S, Cesaro A, Ciccarelli R, Capaldo B, Andria G. Upper airway obstructive disease in mucopolysaccharidoses: polysomnography, computed tomography and nasal endoscopy findings. J Inherit Metab Dis 2007;30:743-749.

31. Brambrink AM, Braun U. Airway management in infants and children. Best Pract Res Clin Anaesthesiol 2005;19:675-697.

32. Myer CM, 3rd, O'Connor DM, Cotton RT. Proposed grading system for subglottic stenosis based on endotracheal tube sizes. Ann Otol Rhinol Laryngol 1994;103:319-323. 


\section{Legends of the Figures}

\section{Figure 1}

Typical acoustic recording curves in a healthy subject

Two-dimensional recording; $\mathrm{X}$ : distance from microphones $(\mathrm{cm}) \mathrm{Y}$ : area of airways' cross-section

1: mouthpiece and filter; 2 : mouth and oropharynx 3: pharynx; 4: larynx and trachea; 5: bronchi (artefacts)

\section{Figure 2}

Selection of subjects eligible for the acoustic reflection measurement among the patients with a mucopolysaccharidosis followed in our institution

\section{Figure 3}

An acoustic reflection tracings in a patient with mucopolysaccharidosis (patient). Note the reduced value of the mean cross sectional area and of the cross-sectional area all along the airway (arrows)

\section{Figure 4}

Mean cross sectional area values and resistance values of the patients with mucopolysaccharidosis and the control subjects; black-filled circles correspond to the 2 patients with mucopolysaccharidosis treated by long term noninvasive positive pressure ventilation. 
Table 1: comparison of the patients with mucopolysaccharidosis able or not to perform an adequate acoustic reflection measurement (ARM)

\begin{tabular}{cc|c}
\hline & $\begin{array}{c}\text { Patients able to } \\
\text { perform an ARM } \\
\text { recording } \\
\mathrm{n}=7\end{array}$ & $\begin{array}{c}\text { Patients unable to } \\
\text { perform an ARM } \\
\text { recording } \\
\mathrm{n}=3\end{array}$ \\
\hline $\begin{array}{c}\text { Age }(\mathrm{y}) \\
\begin{array}{c}\text { Gender } \\
\text { Type of MPS } \\
\text { Type II }\end{array}\end{array}$ & $\begin{array}{c}15.2 \\
\mathrm{M}=6 ; \mathrm{n}=3\end{array}$ \\
$\begin{array}{c}\mathrm{n}=1 \\
\text { Type III }\end{array}$ & 3 & 2 \\
Type IV & 0 & 1 \\
Type VI & 2 & 0 \\
Fucosidosis & 1 & 0 \\
\end{tabular}

y: years; M: male; F: female 
Table 2: characteristics of the patients

\begin{tabular}{|c|c|c|c|c|c|c|c|c|c|c|c|c|c|c|}
\hline Patient & Gender & Condition & $\begin{array}{l}\text { Age } \\
(y)\end{array}$ & $\begin{array}{l}\text { Height } \\
(\mathrm{cm})\end{array}$ & $\begin{array}{l}\text { Weight } \\
(\mathrm{kg})\end{array}$ & $\begin{array}{c}\text { Mental } \\
\text { retardation }\end{array}$ & $\begin{array}{l}\text { History of } \\
\text { difficult } \\
\text { intubation }\end{array}$ & $\begin{array}{c}\text { Sleep } \\
\text { study } \\
<6 \\
\text { months }\end{array}$ & $\begin{array}{c}\text { Minimal } \\
\text { sleep } \mathrm{SpO}_{2}\end{array}$ & $\mathrm{RDI}$ & $\begin{array}{l}\mathrm{DI} \\
(/ \mathrm{h})\end{array}$ & $\begin{array}{c}\text { Snoring } \\
\text { index }\end{array}$ & $\begin{array}{c}\text { Maximal } \\
\text { sleep } \\
\mathrm{CO}_{2} \\
(\mathrm{mmHg})\end{array}$ & NPPV \\
\hline \#1 & M & MPS II: Hunter syndrome & 5.8 & 120 & 30 & Severe & Yes & No & & & & & & No \\
\hline \#2 & M & MPS IV-A: Morquio syndrome & 7 & 110 & 19 & None & No & No & & & & & & No \\
\hline \#3 & M & MPS IV-A: Morquio syndrome & 7.5 & 95 & 17 & None & No & Yes & $93 \%$ & 6 & 0 & 61 & & No \\
\hline \#4 & $\mathrm{F}$ & Fucosidosis & 10.5 & 125 & 25 & Severe & No & No & & & & & & No \\
\hline \#5 & M & MPS II: Hunter syndrome & 11.5 & 135 & 36 & Severe & Yes & Yes & $91 \%$ & 5 & 0 & 55 & 45 & No \\
\hline \#6 & M & MPS II: Hunter syndrome & 15 & 134 & 32 & Severe & Yes & $n / a$ & $65 \%$ & 7 & 34 & 8 & 64 & Yes \\
\hline \#7 & M & $\begin{array}{l}\text { MPS VI: Maroteaux-Lamy } \\
\text { syndrome }\end{array}$ & 15.6 & 131 & 35 & Mild & Yes & $\mathrm{n} / \mathrm{a}$ & $70 \%$ & 17 & 36 & 82 & 53 & Yes \\
\hline
\end{tabular}

M: male; F: female; MPS: mucopolysaccharidosis; y: years; $\mathrm{SpO}_{2}$ : pulse oximetry; RDI: respiratory disturbance index; DI: desaturation index; /h: by hour; $\mathrm{CO}_{2}$ : carbon dioxide; NPPV: noninvasive positive pressure ventilation; n/a: non applicable. 
Table 3: acoustic measurements in MPS patients and healthy subjects

\begin{tabular}{|c|c|c|c|c|c|}
\hline & \multicolumn{2}{|l|}{ MPS patients } & \multicolumn{3}{|c|}{ Healthy subjects } \\
\hline & Mean \pm SD & Range & Mean \pm SD & Range & $\mathbf{p}$ \\
\hline \multicolumn{6}{|l|}{ Anthropometry } \\
\hline Age & $10.4 \pm 3.9$ & $5.8-15.6$ & $7.3 \pm 2$ & 4.1-10.4 & $p=0.04$ \\
\hline Height (cm) & $121.4 \pm 14.6$ & $95-135$ & $120.9 \pm 12$ & $95-133$ & $\mathrm{p}=0.4651$ \\
\hline Weight (kg) & $27.7 \pm 7.5$ & $17-36$ & $26.2 \pm 7.3$ & $19-39$ & $\mathrm{p}=0.3366$ \\
\hline $\mathrm{BMI}\left(\mathrm{kg} \cdot \mathrm{cm}^{-2}\right)$ & $18.5 \pm 2$ & $16-20.8$ & $17.9 \pm 3.5$ & $14.6-22$ & $\mathrm{p}=0.3098$ \\
\hline \multicolumn{6}{|l|}{ Acoustic measurements } \\
\hline $\operatorname{MCAv}\left(\mathrm{cm}^{2}\right)$ & $1.6 \pm 0.3$ & $1.3-2$ & $1.8 \pm 0.3$ & $1.5-2.4$ & $\mathrm{p}=0.0329$ \\
\hline Mean pharyngeal airway surface $\left(\mathrm{cm}^{2}\right)$ & $2.2 \pm 0.6$ & $1.3-2.8$ & $2.5 \pm 0.3$ & $1.9-3.1$ & $\mathrm{p}=0.15$ \\
\hline Mean tracheal airway surface $\left(\mathrm{cm}^{2}\right)$ & $1.8 \pm 0.3$ & $1.3-2.4$ & $2 \pm 0.3$ & $1.7-2.4$ & $p=0.06$ \\
\hline $\mathrm{R}\left(\mathrm{cmH}_{2} \mathrm{O} . \mathrm{I}^{-1} \cdot \mathrm{s}\right)$ & $7.9 \pm 1.8$ & $5.6-10.1$ & $5.5 \pm 1.2$ & 3.3-6.9 & $\mathrm{p}=0.0064$ \\
\hline
\end{tabular}

MPS: mucopolysaccharidosis; SD: standard deviation; BMI: body mass index; R: airway resistance; MCAv: minimal cross-sectional area value 


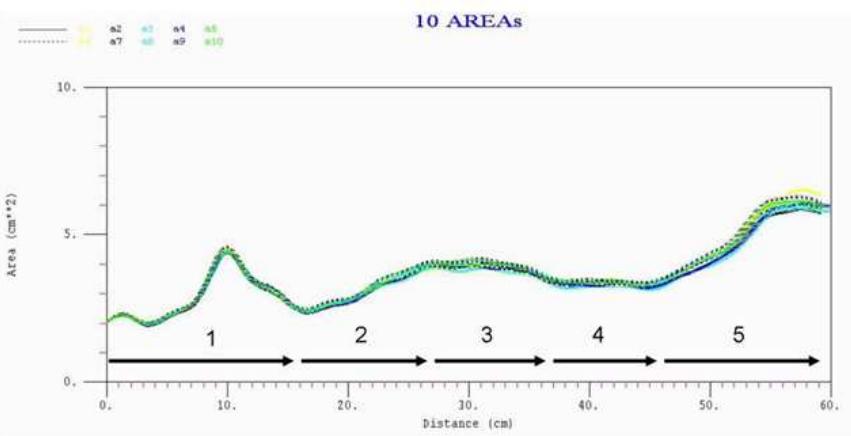

Figure 1 254x190mm (96 x 96 DPI)

John Wiley \& Sons, Inc. 
Figure 2

Figure 2

254x190mm (96 x 96 DPI)

John Wiley \& Sons, Inc. 
Figure 3

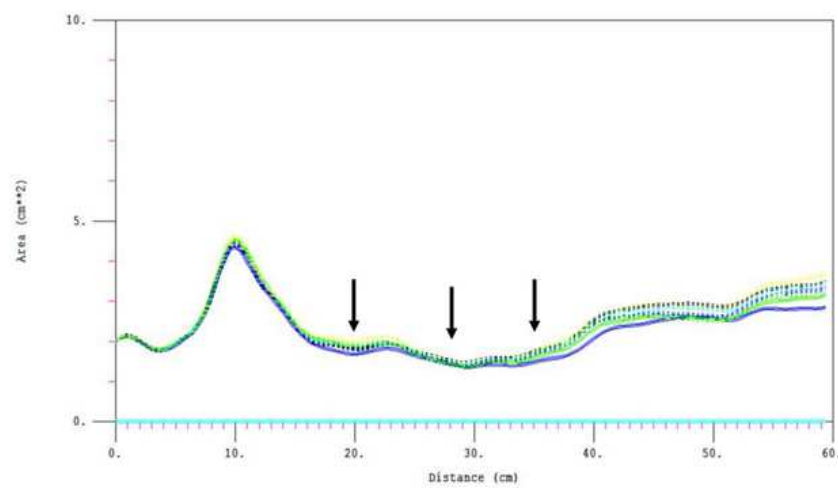

Figure 3

254x190mm (96 x 96 DPI)

John Wiley \& Sons, Inc. 
Figure 4
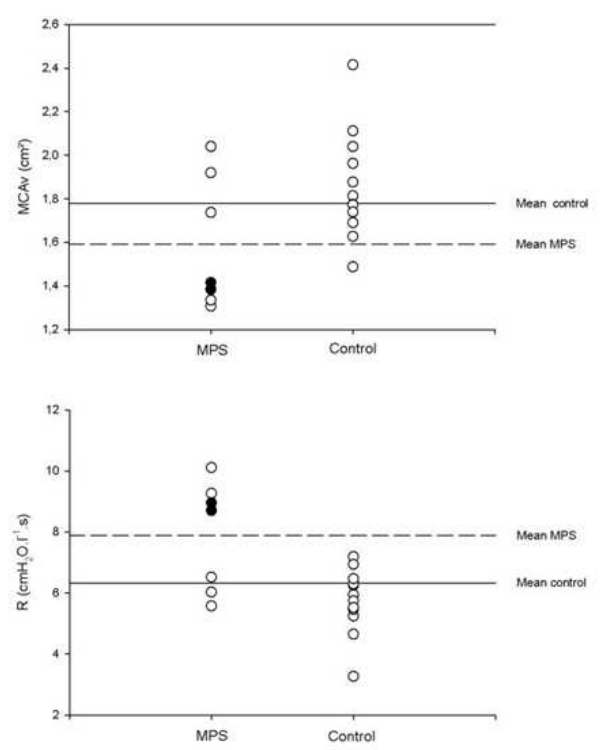

Figure 4 $254 \times 190 \mathrm{~mm}(96 \times 96$ DPI $)$

John Wiley \& Sons, Inc. 